\title{
PENGGUNAAN ENZIM PROTEASE KASAR GETAH BIDURI UNTUK PRODUKSI CITA RASA IKAN TERI (Stolephorus heterolobus)
}

\author{
[Utilizing of Protease Enzymes for The Production of Coarse Sap Biduri Taste \\ Anchovy (Stolephorus heterolobus)] \\ Elfian $^{1^{\star}}$, Mappiratu $^{1}$, Abd. Rahman Razak ${ }^{1}$ \\ 1) Jurusan Kimia, Fakultas Matematika Dan Ilmu Pengetahuan Alam, Universitas Tadulako \\ Jl. Soekarno Hatta Km.9, Kampus Bumi Tadulako Tondo Palu, Telp. 0451- 422611
}

Diterima 20 Maret 2017, Disetujui 27 Mei 2017

\begin{abstract}
The research about utilizing of protease enzymes for the production of coarse sap Biduri taste anchovy (Stolephorus heterolobus)". This study aims to determine the protease concentration and time Biduri hydrolysis produces water content (content of soluble protein, amino acid level) is the highest and panelists preferred. Research using factorial randomized complete block design consisting of two factors: Factor (protease concentration Biduri) (A) consists of 4 levels include: Biduri proteasae concentration of 1.5\% (w/w) (A1); $2 \%(\mathrm{w} / \mathrm{w})(\mathrm{A} 2) ; 2.5 \%(\mathrm{w} / \mathrm{w})(\mathrm{A} 3)$ and $3 \%(\mathrm{w} / \mathrm{w})(\mathrm{A} 4)$. And factors (long hydrolysis) (B) consists of 3 levels include: long hydrolysis $0.5 \mathrm{~h}$ (B1); 1 hour (B2); and 1.5 hours (B3) Each combination treatment was repeated 3 times, so that each contained 12 units experiment is a factor. The best combination present in $2.5 \%$ protease rough sap Biduri with hydrolysis time of 1.5 hours which resulted in water levels (levels of soluble protein, amino acid level) is the highest and panelists preferred.
\end{abstract}

Keywords: anchovies, Biduri protease enzymes, amino acids, organoleptic

\begin{abstract}
ABSTRAK
Telah dilakukan penelitian tentang "Penggunaan enzim protease kasar getah biduri untuk produksi cita rasa ikan teri (Stolephorus heterolobus)". Penelitian ini bertujuan untuk mengetahui konsentrasi protease biduri dan waktu hidrolisis yang menghasilkan kadar air (kadar protein terlarut, kadar asam amino) tertinggi dan disukai panelis. Penelitian menggunakan rancangan acak kelompok pola faktorial yang terdiri atas dua faktor yaitu : Faktor (konsentrasi protease biduri) (A) terdiri atas 4 taraf meliputi: konsentrasi proteasae biduri 1,5\% (w/w) (A1) ; $2 \%(\mathrm{w} / \mathrm{w})(\mathrm{A} 2) ; 2,5 \%(\mathrm{w} / \mathrm{w})(\mathrm{A} 3)$ dan 3 $\%(\mathrm{w} / \mathrm{w})(\mathrm{A} 4)$. Dan Faktor (lama hidrolisis) (B) terdiri atas 3 taraf meliputi : lama hidrolisis 0,5 jam (B1); 1 jam (B2); dan 1,5 jam (B3) Masing-masing kombinasi Perlakuan diulang 3 kali, sehingga setiap faktor terdapat 12 unit percobaaan. Kombinasi terbaik terdapat pada penggunaan 2,5\% protease kasar getah biduri dengan waktu hidrolisis 1,5 jam yang menghasilkan kadar air (kadar protein terlarut, kadar asam amino) tertinggi dan disukai panelis.
\end{abstract}

Kata Kunci: Ikan teri, Enzim protease biduri, asam amino, organoleptik. 
LATAR BELAKANG

Tanaman Biduri (Calotropis gigantea) merupakan jenis tanaman semak yang hanya tumbuh liar pada daerah kering termasuk di Sulawesi. Tanaman ini tumbuh subur di kota Palu. Dari seluruh bagian tanaman biduri akan mengalir getah pada tempat yang dilukai atau dipotong (Stenis, 1992). Witono (2002) melaporkan bahwa ekstrak dari tanaman biduri baik dari getah, daun, maupun batang memiliki potensi tinggi sebagai sumber penghasil enzim protease.

Protease merupakan jenis enzim hidrolase yang bekerja dengan mendegradasi protein dan banyak dimanfaatkan pada industri pangan, seperti pengempuk daging, pembuatan keju, pembuatan roti, penjernih bir, pembuatan hidrolisat protein, dan lain sebagainya. Enzim protease dari biduri sangat berpotensi ebagai katalis aktif dalam produksi cita rasa atau flavor (Witono, 2006).

Senyawa cita rasa merupakan salah satu faktor yang menentukan kualitas makanan. Senyawa ini dapat diperoleh dari protein hewani dan nabati, seperti ikan teri. Ikan teri adalah lauk favorit masyarakat Indonesia dan ikan ini tersebar hampir di seluruh perairan Indonesia. Kadar protein dalam ikan teri adalah 10,3\%. Berdasarkan data tersebut menunjukan bahwa ikan teri sangat potensial untuk produksi cita rasa ikan teri. Cita rasa ikan teri yang terbentuk diharapkan mampu menggantikan peranan penyedap rasa mononatrium glutamat (MSG). Senyawa MSG yang terakumulasi dalam tubuh manusia secara terus menerus akan menyebabakan efek negatif bagi kesehatan (Ardyanto, 2004).

Hardi dan Diharnaini (2014) telah melakukan produksi cita rasa menggunakan protease getah biduri. Hasil yang mereka peroleh menunjukkan konsentrasi protease getah biduri berpengaruh terhadap kadar air, kadar protein terlarut dan mutu organoleptik, sedangkan waktu hidrolisis hanya berpengaruh terhadap kadar protein terlarut dan mutu organoleptik. Witono (2007), melaporkan bahwa pada konsentrasi protease biduri dan waktu hidrolisis yang semakin tinggi dan lama, akan mengakibatkan kadar protein terlarut flavor dari kedelai semakin tinggi. Melalui teknik hidrolisis protein dengan menggunakan katalis yang spesifik dari suatu bahan dapat diubah menjadi senyawa asam amino bentuk $L$ dan berbagai ragam peptida yang memrupakan senyawa cita rasa (Kunts, 2000).

Berdasarkan hal tersebut, maka pengembangan sumber cita rasa alami sangat perlu dilakukan. Diharapkan cita rasa alternatif tersebut tidak hanya berfungsi dalam menciptakan rasa gurih (umami) pada makanan, tetapi juga memberikan peran nutrisi dan aman bagi kesehatan. 


\section{METODE PENELITIAN}

\section{Bahan dan Peralatan}

Alat yang digunakan dalam penelitian ini adalah freeze driyer, oven analitik, neraca analitik, talang, baskom plastik, lemari pendingin, kertas saring, penangas air (Schutzart 40500 - Ip 20), blender (stainless steel), pemanas listrik (hot plate), spektrofotometer UV Visibel (UNICO 1100 RS), moisture anlyzer (Citizen MB 200), ayakan 80 mesh, baskom palstik, dan alat-alat gelas yang umum digunakan di Laboratorium Kimia.

Bahan baku digunakan dalam penelitian adalah ikan teri yang dibeli dari pasar Impres Palu, dan getah biduri yang diperoleh disekitar perumahan Dosen Untad. Bahan kimia yang digunakan adalah amonium sulfat (pupuk Z.A), buffer phospat ( $\mathrm{pH}$ 7) dan CMC (Carboxy Methyl Celluolse). Serta bahan lain seperti, gula, garam dan aquadest.

\section{Rancangan penelitian}

Penelitian ini dirancang menggunakan Rancangan Acak Kelompok pola Faktorial yang terdiri atas dua faktor yaitu : Faktor (konsentrasi protease biduri) (A) terdiri atas 4 taraf meliputi : konsentrasi proteasae biduri 1,5 $\%(w / w)(A 1) ; 2 \%(w / w)$ (A2) ; 2,5\% (w/w) (A3) dan $3 \%(w / w)$ (A4). Dan Faktor (lama hidrolisis) (B) terdiri atas 3 taraf meliputi : lama hidrolisis 0,5 jam (B1); 1 jam (B2); dan 1,5 jam (B3) Masing-masing kombinasi Perlakuan diulang 3 kali, sehingga setiap faktor terdapat 12 unit pecobaaan.

\section{Prosedur Penelitian}

Penelitian yang dilakukan ini terdiri atas beberapa tahap kerja, yaitu isolasi enzim protease kasar getah biduri, pembuatan tepung ikan teri, kajian konsentrasi biduri dan waktu reaksi dalam hidrolisis protein ikan teri.

\section{Isolasi Enzim Protease Kasar Getah Biduri (Hardi dan Diharnaini, 2014)}

Getah tanaman biduri dipanen saat pagi hari agar getah yang diperoleh lebih banyak. Getah biduri yang terkumpul diukur volumenya sebanyak $600 \mathrm{~mL}$ dan ditepatkan 1 Liter menggunakan aquades. Larutan getah biduri dimasukan kedalam gelas kimia, kemudian ditambahkan amonium sulfat sebanyak 650 gram (tingkat kejenuhan 65\%). Campuran selanjutnya didinginkan di dalam lemari pendingin selama 24 jam. Bagian menggumpal yang terletak dipermukaan, dipisahkan dan disaring dengan kertas saring berlipat. Endapan yang dihasilkan dikeringkan di dalam freeze drayer pada suhu $45^{\circ} \mathrm{C}$ hingga kering. Kemudian enzim protease kasar kering ditimbang untuk mengetahui rendemennya.

\section{Pembuatan Tepung Ikan Teri}

Ikan teri yang telah dicuci dikukus selama 2 jam, dipress kemudian dijemur dibawah sinar matahari. Daging ikan teri yang telah kering diblender kemudian diayak menggunakan ayakan 80 mesh dengan tujuan memperoleh tepung ikan teri dalam keadaan kering. 
Hidrolisis Tepung Ikan Teri dengan Isolat Enzim Protease Kasar Getah Biduri

Pelaksanaan hidrolisis dirancang menggunakan Rancangan Acak Kelompok Pola faktorial. Parameter yang diamati adalah kadar air, kadar protein terlarut dan mutu organoleptik yang meliputi rasa, aroma, warna, dan tingkat kesukaan. Reaksi hidrolisis dilakukakan dengan cara : tepung ikan teri dengan jumlah tertentu dicampurkan dengan larutan buffer fosfat $\mathrm{pH} 7$ dengan rasio bahan 1: $8(\mathrm{w} / \mathrm{v})$. suspensi tepung ikan teri yang dihasilkan selanjutkan ditambahkan enzim protease kasar pada konsentrasi tertentu (sesuai Perlakuan). Campuran selanjutnya dipanaskan dalam penangas air suhu $55^{\circ} \mathrm{C}$ (suhu optimum protease) dengan waktu tertentu (sesuai Perlakuan), setelah itu dimasukan dalam air mendidih selama 10 menit untuk menonaktifkan enzim. Campuran selanjutnya ditambahkan dengan 1\% CMC; $2 \%$ gula; dan $2 \%$ garam dapur. Atas dasar berat ikan teri sambil diaduk sampai mengental, kemudian dihamparkan dalam loyang dan dikeringkan dalam oven analitik pada suhu $45^{\circ} \mathrm{C}$. Setelah kering diblender dan diayak dengan ayakan 80 mesh. Hasil ayakan dianalisis kadar air, kadar protein terlarut, kadar asam amino, dan mutu organoleptik meliputi warna, aroma, rasa dan kesukaan.

\section{HASIL DAN PEMBAHASAN}

\section{Kadar Air Produk Cita Rasa Ikan Teri}

Whittaker (1994) yang diacu dalam Witono (2007) menyatakan bahwa selain mengurangi berat molekul polipeptida, hidrolisis atau degradasi protein juga menyebabkan kerusakan struktur globular protein sehingga keterikatan air menjadi berkurang.

Daya awet suatu bahan pangan sangat ditentukan oleh kandungan air bahan pangan tersebut. Bahan pangan dinyatakan awet dalam arti tidak rusak oleh mikroorganisme, jika kadar airnya tidak lebih dari 12\% (Mappiratu, 2007).

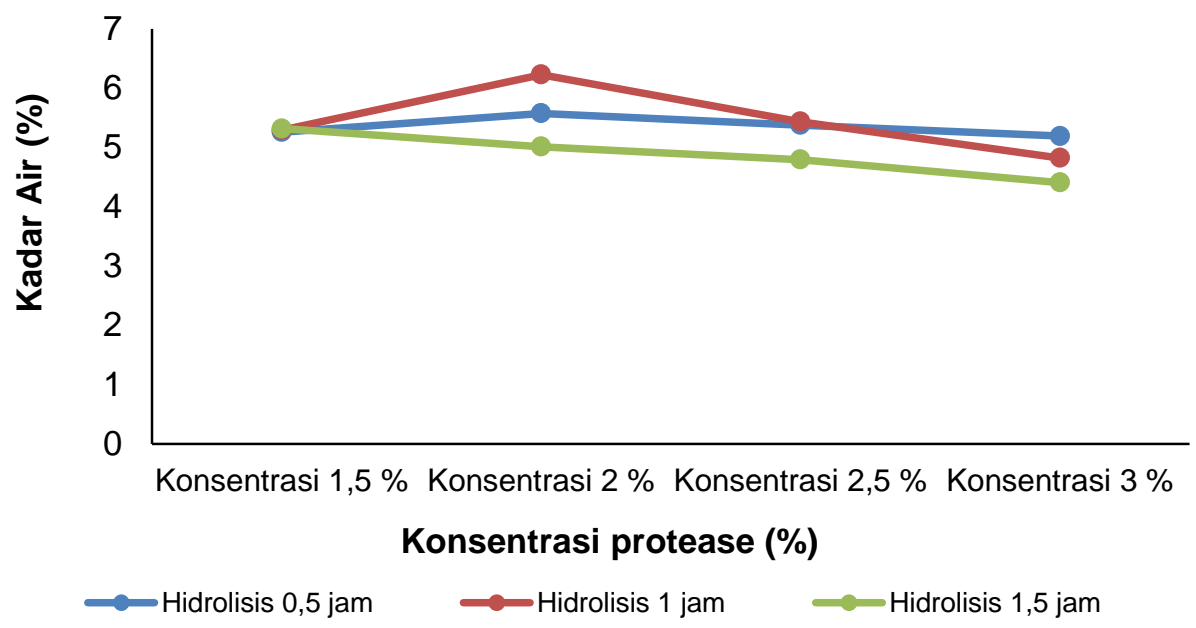

Gambar 1. Kurva kadar air produk cita rasa ikan teri pada berbagai konsentrasi protease dan waktu hidrolisis. 
Hasil analisis yang diperoleh (Gambar 1) menunjukkan kadar air cita rasa ikan teri tertinggi $(6,22 \%)$ terdapat pada penggunaan $2 \%$ protease biduri dengan waktu hidrolisis 1 jam, sedangkan kadar air terendah $(4,4 \%)$ terdapat pada penggunaan $3 \%$ protease biduri dengan waktu hidrolisis 1,5 jam.

Hasil analisis ragam menunjukan tidak terdapat interaksi antara konsentrasi protease dengan waktu hidrolisis terhadap kadar air cita rasa ikan teri. Konsentrasi protease biduri berpengaruh terhadap kadar air cita rasa ikan teri. sedangkan waktu hidrolisis tidak berpengaruh. Hal ini menunjukan terdapat perbedaan kadar air pada waktu hidrolisis yang berbeda.

Dengan mengacu pada kadar air yang aman terhadap kerusakan mikrobiologi, maka cita rasa ikan teri yang dihasilkan dari penggunaan konsentrasi pro=tease biduri 1,5; 2, 2,5 dan $3 \%$ dengan waktu hidrolisis 0,$5 ; 1$ jam dan 1,5 jam sudah masuk dalam kategori aman dari kerusakan, sebab kadar airnya kurang dari $12 \%$.

Witono (2007) melaporkan kadar air produk cita rasa kedelai menurun dengan meningkatnya konsentrasi protease biduri. Sebagaimana yang dikemukakan Whittaker (1994) dalam Witono (2007) bahwa selain menurunkan berat molekul polipeptida, hidrolisis protein juga menyebabkan kerusakaan dari struktur globular protein, sehingga kemampuan mengikat air menjadi berkurang. Hasil yang didapatkan tidak sesuai dengan literatur yang ada, hal ini diasumsikan pengeringan yang menggunakan pengering surya di mana suhu matahari yang tidak konstan menyebabkan kadar air naik turun.

\section{Kadar Protein Terlarut Produk Cita Rasa Ikan Teri}

Protein tidak larut dapat dihidrolisis menjadi protein terlarut dengan menggunakan enzim protease yang memutus ikatan pada polipeptida protein menjadi peptida yang lebih sederhana. Sebagaimana dilaporkan oleh Hrckova et al. (2002) bahwa jumlah asam amino bebas dari hidrolisis protein kedelai bebas lemak menggunakan protease selektif juga meningkat seiring dengan lamanya waktu inkubasi.

Hasil yang diperoleh (Gambar 2) menunjukkan bahwa kadar protein terlarut tertinggi $(27,1 \%)$ terdapat pada penggunaan $1,5 \%$ protease biduri dengan waktu hidrolisis 1,5 jam, sedangkan kadar protein terlarut terendah (15,5\%) ditemukan pada penggunaan 1,5\% protease biduri dengan waktu hidrolisis 0,5 jam.

Hasil analisis ragam menunjukkan terdapat interaksi antara konsentrasi protease biduri dengan waktu hidrolisis terhadap kadar protein terlarut cita rasa ikan teri. Konsentrasi protease biduri berpengaruh nyata terhadap kadar protein terlarut cita rasa ikan teri, sedangkan waktu hidrolisis berpengaruh sangat nyata. 


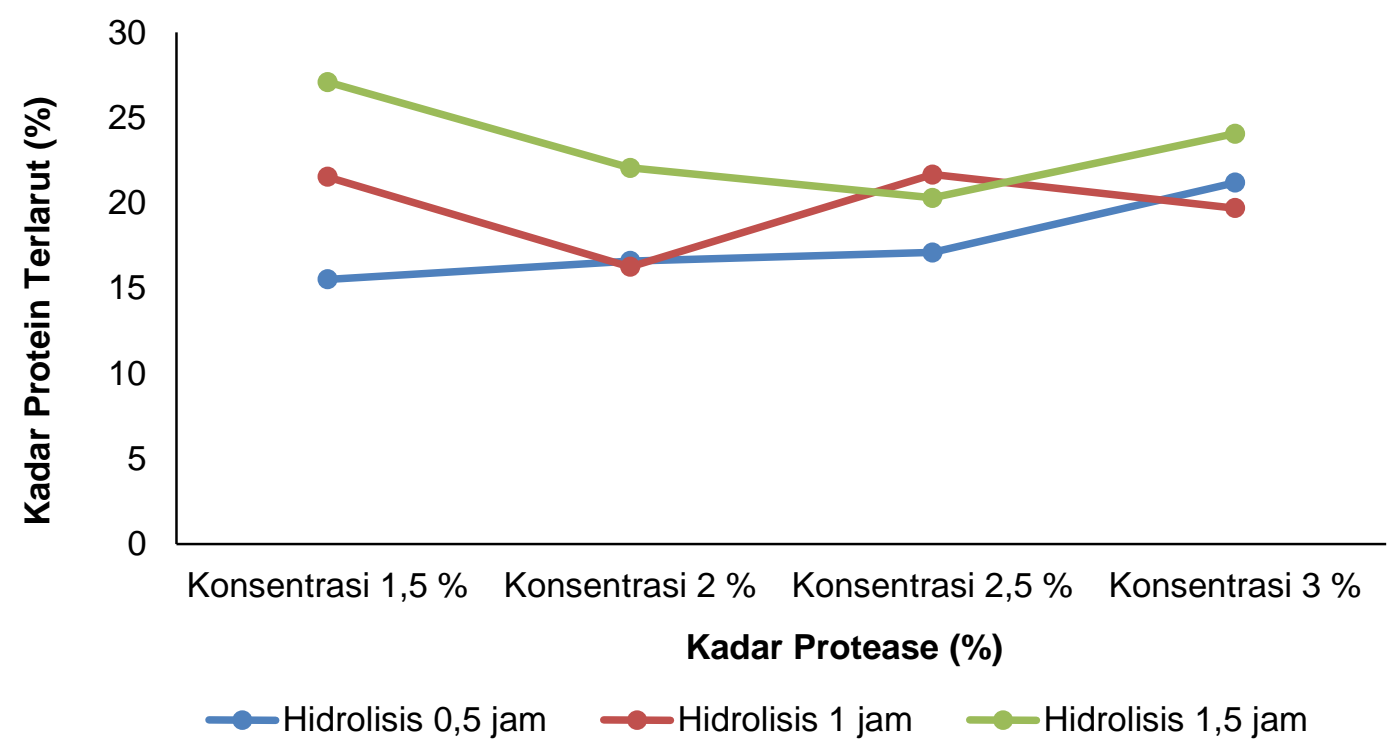

Gambar 2. Kurva Kadar protein terlarut produk cita rasa ikan teri pada berbagai konsentrasi protease dan waktu hidrolisis.

Protein terlarut pada penggunaan $1,5 \%$ protease biduri dengan waktu hidrolisis 1,5 jam adalah kombinasi terbaik dengan kadar protein terlarut yaitu $(27,1 \%)$. Hasil tersebut menunjukkan bahwa hidrolisat protein ikan teri lebih banyak membentuk peptida-peptida rantai pendek dan asam amino bentuk $L$ yang merupakan sumber pembentuk cita rasa.

Sebagaimana yang dilaporkan oleh (Witono 2007) bahwa konsentrasi protease biduri yang semakin tinggi dan waktu hidrolisis yang semakin lama, akan menyebabkan kadar protein terlarut cita rasa kedelai semakin tinggi. Peristiwa tersebut terjadi karena enzim proteaseakan memecah protein menjadi peptida - peptida sederhana dan asamasam amino yang mudah larut.

\section{Kadar Asam Amino Produk Cita Rasa Ikan Teri}

Menurut Nielsen (1997) semakin besar konsentrasi protease biduri dan semakin lama waktu hidrolisis, maka kadar protein terlarut hidrolisat kedelai semakin tinggi. Hal ini karena enzim protease bersifat memecah protein menjadi peptida pendek dan asam-asam amino yang mudah larut.

Hasil yang diperoleh (Gambar 3) menunjukkan bahwa kadar asam amino tertinggi $(1,396 \%)$ terdapat pada penggunaan $3 \%$ protease biduri dengan waktu hidrolisis 1 jam, sedangkan kadar asam amino terendah (1,186 \%) didapatkan pada penggunaan 1,5\% protease biduri dan waktu 0,5 jam.

Hasil analisis ragam menunjukkan tidak terdapat interaksi antara konsentrasi protease biduri dengan waktu hidrolisis terhadap kadar protein terlarut cita rasa ikan teri. Konsentrasi protease biduri berpengaruh sangat nyata terhadap kadar asam amino cita rasa ikan teri, sedangkan waktu hidrolisis berpengaruh tidak nyata. 


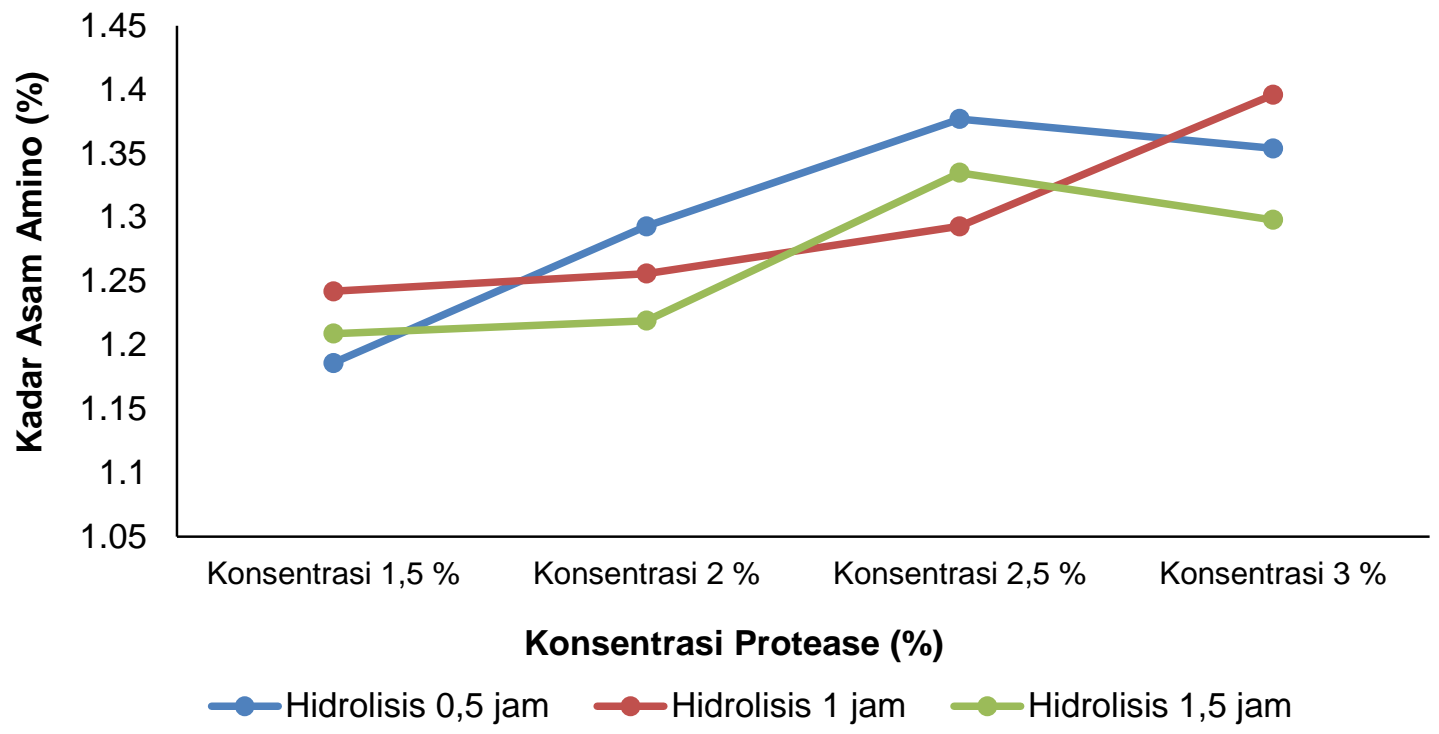

Gambar 3. Kurva Kadar asam amino produk cita rasa ikan teri pada berbagai konsentrasi protease dan waktu hidrolisis

Secara mekanisme, enzim protease biduri memecah polipeptida menjadi peptida-peptida dan asam amino sederhana yang mudah larut. Begitu pula waktu hidrolsis yang lama mengakibatkan interaksi antara substrat dengan enzim semakin lama sehingga semakin meningkatkan jumlah protein sederhana yang sangat mudah untuk larut.

\section{Mutu Organoleptik Produk Cita Rasa Ikan Teri}

Hidrolisis protein akan mengakibatkan terjadinya perubahan cita rasa yang disebabkan oleh terbentuknya peptida - peptida rantai pendek dan asam amino yang berperan dalam pembentukan cita rasa gurih pada hidrolisat protein ikan teri yang dihasilkan. Rasa gurih dari hidrolisat protein lebih dikenal dengan istilah umami (Hardi dan Diharnaini, 2014).
Untuk mengetahui tingkat kesukaan terhadap cita rasa ikan teri, baik warna, gurih, aroma maupun tingkat kesukaan, maka dilakukan uji mutu hedonik pada 30 panelis dengan kisaran respon $1-7$ untuk masing-masing atribut. Misalkan uji kesukaan, nilai $1=$ sangat tidak suka, $2=$ tidak suka, $3=$ agak tidak suka, $4=$ netral, $5=$ agak suka, $6=$ suka, $7=$ sangat suka .

\section{Rasa Gurih Produk Cita Rasa Ikan Teri}

Rasa gurih merupakan hal yang paling mendukung dalam pembentukan cita rasa. Hasil yang diperoleh (Gambar 4) menunjukkan tingkat kesukaan rasa gurih cita rasa ikan teri tertinggi adalah pada penggunaan $2,5 \%$ protease biduri dengan waktu hidrolisis 1,5 jam sebesar 5,133 (agak gurih). Sedangkan tingkat kesukaan rasa gurih cita rasa ikan teri terendah adalah pada penggunaan $2 \%$ protease biduri dengan waktu hidrolisis 1,5 jam sebesar 3,867 (agak tidak gurih). 


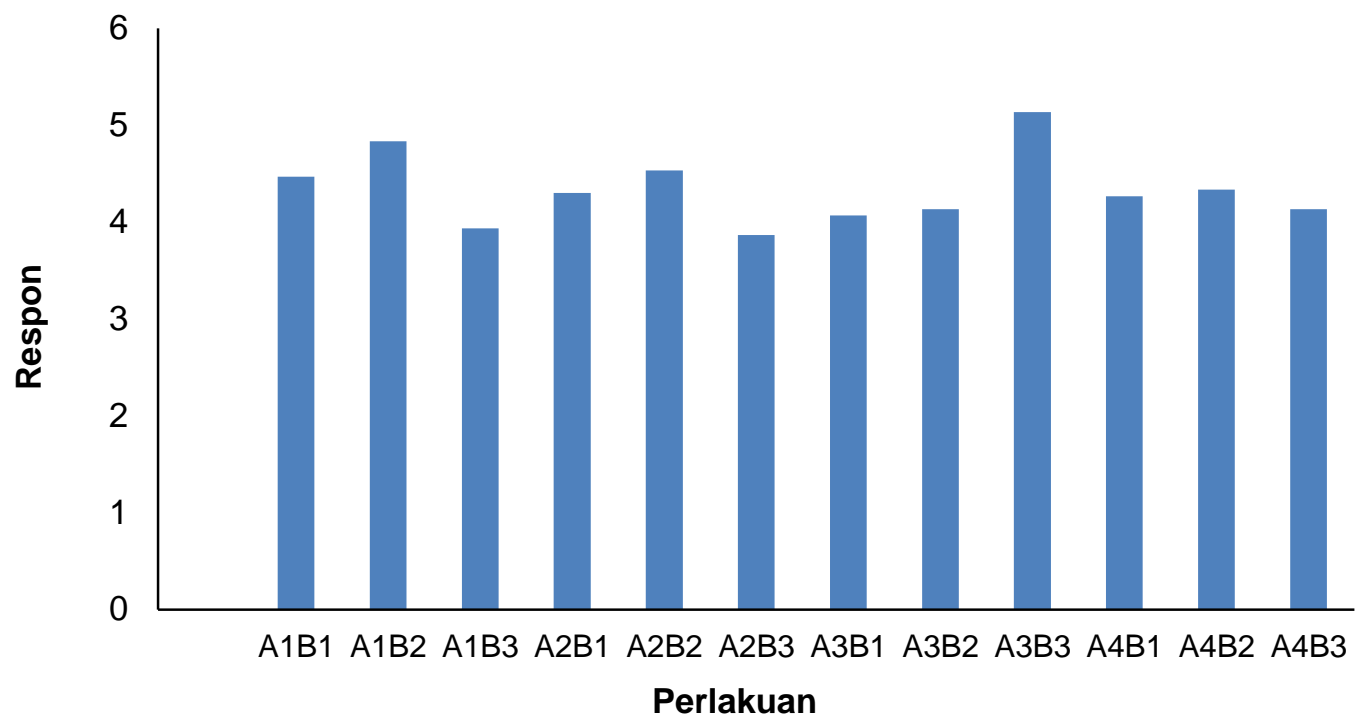

Gambar 4. Histogram uji mutu hedonik untuk sifat gurih produk cita rasa ikan teri

Pada Gambar 4 memperlihatkan bahwa tingkat kesukaan rasa gurih hanya berkisar pada rasa agak tudak gurih sampai dengan agak gurih. Hasil analisis ragam menunjukkan tidak terdapat interaksi antara konsentrasi protease biduri dengan waktu hidrolisis terhadap rasa gurih cita rasa ikan teri. Konsentrasi protease biduri berpengaruh tidak nyata pada perubahan rasa gurih dari cita rasa ikan teri, begitu pula pada waktu hidrolisis. Dengan demikian tidak terdapat perbedaan rasa gurih cita rasa ikan teri yang berarti pada berbagai konsentrasi protease biduri dan waktu hidrolisis.

\section{Aroma Produk Cita Rasa Ikan Teri}

Aroma dapat terbentuk dari gula yang ditambahkan, asam amino bebas, peptida-peptida, nukleotida, dan asamasam organik yang berperan sebagai prekursor utama dalam pembentukan cita rasa gurih pada hidrolisat yang dihasilkan.

Tingkat aroma yang ditimbulkan sangat tergantung dari proses hidrolisis, dimana aroma yang dihasilkan sangat khas aroma ikan teri. Hasil yang diperoleh (Gambar 5) menunjukkan tingkat kesukaan aroma cita rasa ikan teri tertinggi adalah pada penggunaan 1,5\% protease biduri dengan waktu hidrolisis 1 jam sebesar 4,867 (netral) Sedangkan tingkat kesukaan aroma cita rasa ikan teri terendah adalah pada penggunaan $3 \%$ protease biduri dengan waktu hidrolisis 1,5 jam sebesar 3,833 (agak tidak harum).

Pada Gambar 5 memperlihatkan bahwa tingkat kesukaan aroma cita rasa ikan teri berkisar pada aroma netral sampai dengan agak tidak harum. Hasil analisis ragam menunjukkan terdapat interaksi antara konsentrasi protease biduri dengan waktu hidrolisis terhadap aroma cita rasa ikan teri. Konsentrasi protease biduri berpengaruh nyata pada perubahan aroma cita rasa ikan teri begitu pula pada waktu hidrolisis 


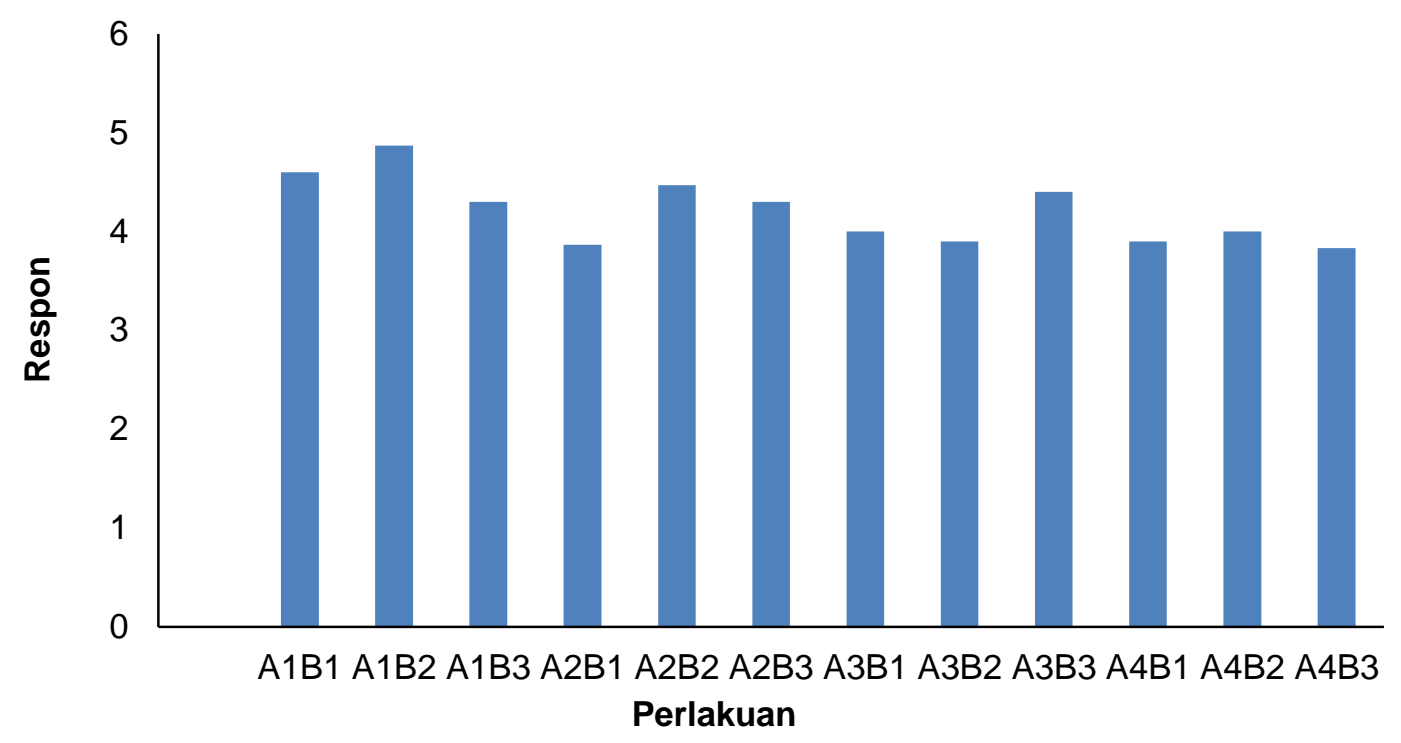

Gambar 5. Histogram uji mutu hedonik untuk sifat harum produk cita rasa ikan teri

\section{Warna Produk Cita Rasa Ikan Teri}

Warna cita rasa ikan teri yang ditimbulkan sangat tergantung dari proses hidrolisis, dimana warna yang dihasilkan adalah warna coklat khas pada ikan teri.

Hasil yang diperoleh (Gambar 6) menunjukkan tingkat kesukaan warna produk cita rasa ikan teri tertinggi adalah pada penggunaan 1,5\% protease biduri dengan waktu hidrolisis 1 jam sebesar 5,2 (agak coklat). Sedangkan tingkat kesukaan warna cita rasa ikan teri terendah adalah pada penggunaan $3 \%$ protease biduri dengan waktu hidrolisis 1,5 jam sebesar 4,003 (netral).

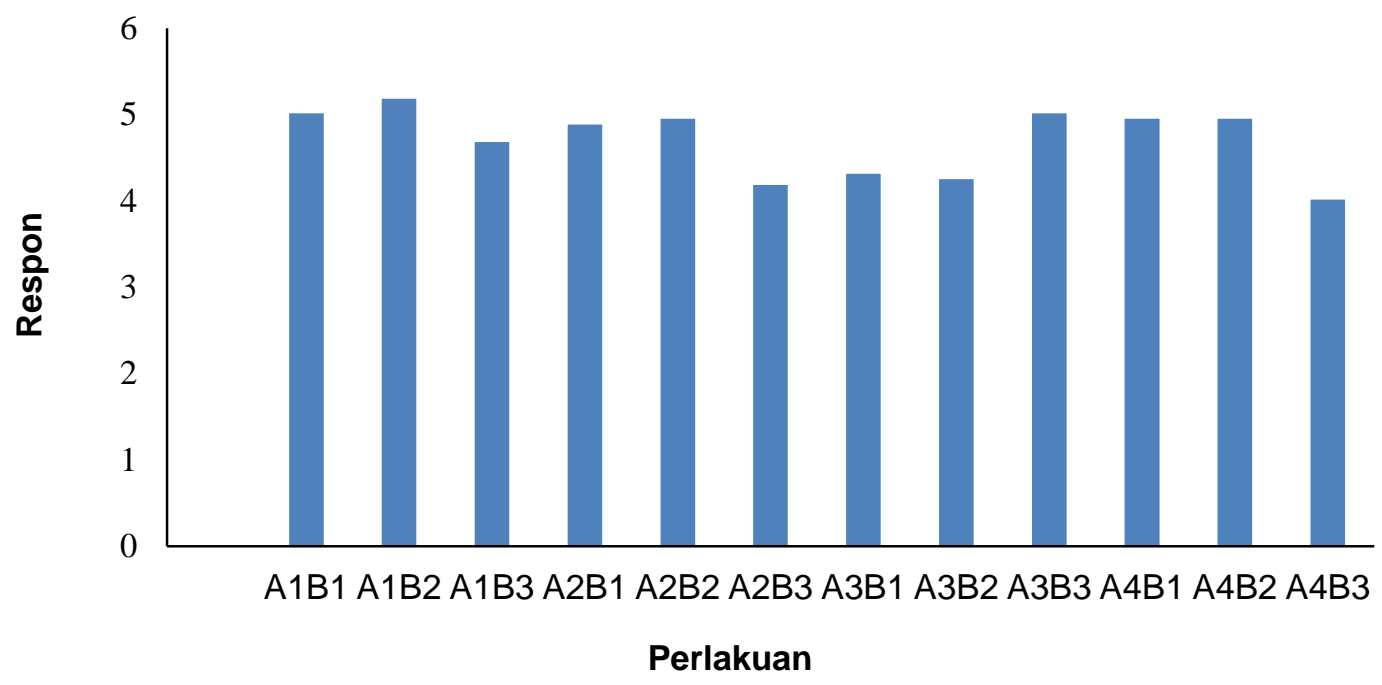

Gambar 6. Histogram uji mutu hedonik untuk sifat warna produk cita rasa ikan teri.

Pada Gambar 6 menunjukkan tingkat kesukaan warna cita rasa ikan teri berkisar pada warna netral sampai dengan agak coklat. Hasil analisis ragam menunjukkan terdapat interaksi yang sangat nyata antara konsentrasi protease 
biduri dengan waktu hidrolisis terhadap warna cita rasa ikan teri. Konsentrasi protease biduri dan waktu hidrolisis berpengaruh sangat nyata pada perubahan warna cita rasa ikan teri.

Peristiwa tersebut terjadi saat ikan teri dipanaskan secara menyeluruh. Semakin besar konsentrasi protease biduri menghasilkan hidrolisat cita rasa ikan teri yang semakin gelap (kecoklatan). Hal ini terjadi karena pada saat proses hidrolisis terjadi pemutusan ikatan peptida oleh enzim protease menghasilkan gugus amina yang merupakan prekursor reaksi Maillard, di mana pada keadaan ini gugus amina protein bereaksi dengan gugus aldehid atau keton dari gula pereduksi yang menghasilkan warna coklat. Semakin banyak konsentrasi protease biduri yang digunakan, maka produk Maillard yang dihasilkan semakin tinggi, sehingga cita rasa ikan teri yang dihasilkan semakin gelap.

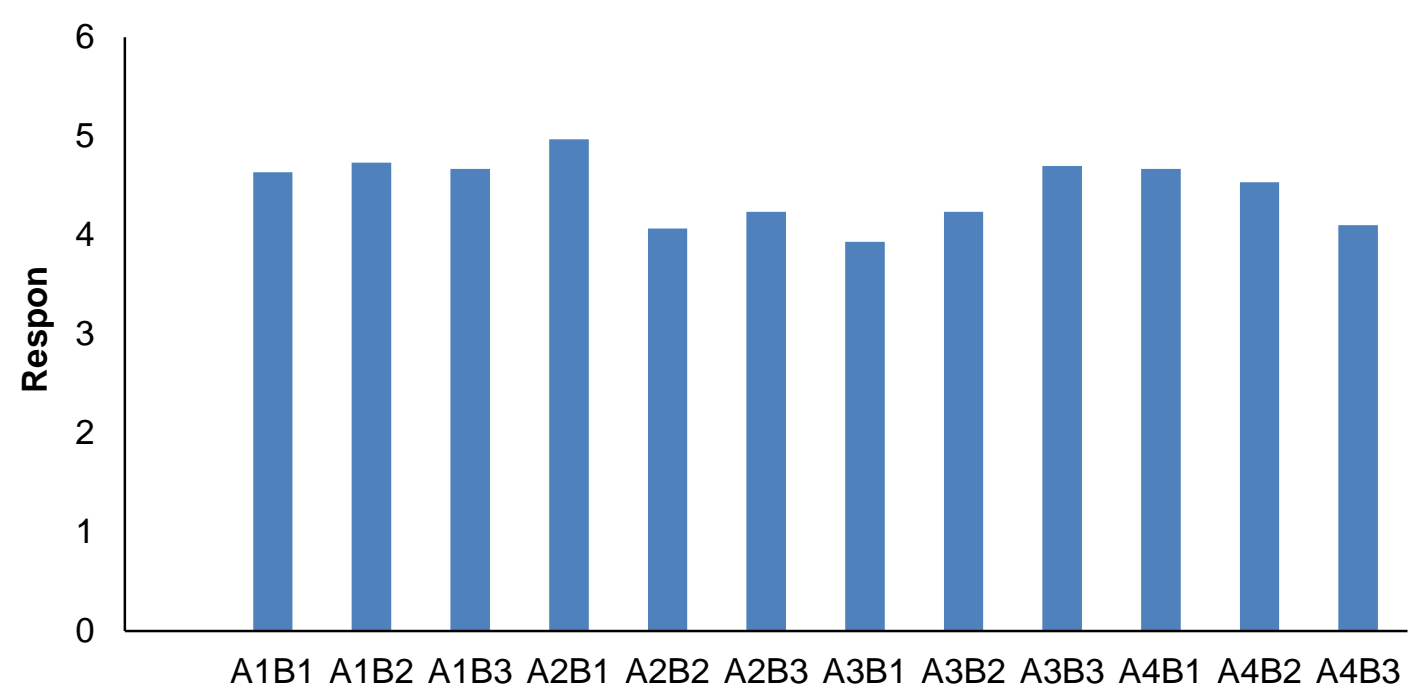

Perlakuan

Gambar 7. Histogram uji mutu hedonik untuk tingkat kesukaan produk cita rasa ikan teri.
Demikian juga, semakin lama hidrolisis, maka hidrolisat protein kedelai yang dihasilkan semakin gelap (kecoklatan). Hal ini karena semakin lama hidrolisis nilai produk Maillard yang dihasilkan semakin banyak sehingga warna hidrolisat semakin gelap. Hasil ini sesuai dengan penelitian Subagio dan Morita (1997).

\section{Uji Kesukaan Produk Cita Rasa}

\section{Ikan Teri}

Kesukaan terhadap cita rasa ikan teri tergantung dari tingkat kesukaan para panelis. Hasil yang diperoleh (Gambar 7) menunjukkan tingkat kesukaan cita rasa ikan teri tertinggi adalah pada penggunaan $2 \%$ protease biduri dengan waktu hidrolisis 0,5 jam sebesar 4,967 (netral). Sedangkan tingkat kesukaan cita rasa ikan teri terendah adalah pada penggunaan $2,5 \%$ protease biduri dengan waktu hidrolisis 0,5 jam sebesar 3,933 (agak tidak suka). 
Pada Gambar 7 memperlihatkan bahwa tingkat kesukaan cita rasa ikan teri hanya berkisar pada agak tidak suka sampai dengan netral. Hasil analisis ragam menunjukkan terdapat interaksi antara konsentrasi protease biduri dengan waktu hidrolisis terhadap kesukaan pada cita rasa ikan teri. Konsentrasi protease biduri tidak berpengaruh nyata pada perubahan kesukaan pada cita rasa ikan teri, begitupula pada waktu hidrolisis. Dari hasil yang didapatkan tidak terdapat perbedaan tingkat kesukaan cita rasa ikan teri yang berarti pada konsetrasi protease.

\section{KESIMPULAN}

Berdasarkan hasil penelitian yang diperoleh, maka dapat disimpulkan bahwa kadar air ( kadar protein terlarut, kadar asam amino) tertinggi terdapat pada penggunaan getah biduri 2,5\% dengan waktu hidrolisis 1,5 jam. Tingkat kesukaan panelis terhadap warna, aroma dan rasa gurih produk cita rasa ikan teri terdapat pada penggunaan protease kasar konsentrasi 2,5\% dan waktu hidrolisis 1,5 jam. Selanjutnya perlu dilakukan penelitian lebih lanjut tentang produksi hidrolisat protein ikan teri menggunakan protese biduri dengan bahan dasar isolat protein ikan teri.

\section{UCAPAN TERIMAKASIH}

Secara khusus $\quad$ peneliti
menyampaikan ucapan terima kasih
kepada Jaya Hardi S.Si., M.Si dan Dewi
Indriani S.Si.

\section{DAFTAR PUSTAKA}

Ardyanto TD. 2004. MSG dan Kesehatan : Sejarah, Efek dan Kontroversinya. Inovasi. 1(16) : 52-56.

Hardi, J., \& Diharnaini, D. (2014). Penggunaan Protease dari Getah Biduri dalam Produksi Flavor Udang Windu (Penaeus monodon). Natural Science: Journal of Science and Technology, 3(2).

Hrckova M. Rusnakova M., Emanovic J. 2002. Enzymatic Hydrolysis of Defatted Soy Flour by Three Different Proteases and their Effect on the Functional Properties of Resulting Protein Hydrolysates. Czech J. Food Sci. 20(1): 7-14.

Kunts A. 2000. Enzymatic Modification of Soy Proteins to Improve Their Functional Properties. Magazine of Industrial Protein. 8(3): 9-11.

Mappiratu H. 2007. Pengolahan Hasil Pertanian. Palu: Tadulako University. Press.

Nielsen PM. 1997. Food Proteins and Their Applications. Marcel Dekker. Inc. New York. Pelletier A., Sygusch J. 1990. Purification and Characterization of Three Chitosanase Activities from Bacillus megaterium $\mathrm{P} 1$. Applied and Enviromental Microbiology. 56(4): 844-848.

Stenis. T. 1992. Flora. Jakarta: Pradnya Paramita.

Subagio A., Morita N. 1997. Changes in Carotenoids and Their Fatty Acid Esters in Banana Peel during Ripening. Food Sci. Technol. 3(3): 264-268.

Whitaker JR. 1994. Principle of Enzymology for the Food Science. New York: Marcel Decker, hlm. 2962.

Witono Y. 2002. Isolasi dan Karakterisasi Enzim Protease dari Getah Tanaman Biduri. J. Teknologi Hasil Pertanian. 1(1): 1-14. 
Witono Y. Subagio A. Susanto T., Widjanarko SB. 2006. Telaah Teknik Produksi Enzim Protease dari Tanaman Biduri (Calotropis gigantea). Reviewer: pDr. Afaf Baktir. MSi. Apt. Prosiding Seminar Nasional Perhimpunan Ahli Teknologi Pangan Indonesia, Yogyakarya.
Witono Y. Aulanni'am. Subagio A. Widjanarko SB. 2007.Karakterisasi Hidrolisat Protein Kedelai Hasil Hidrolisis Menggunakan Protease dari Tanaman Biduri (Calotropis gigantea). Jurnal Penelitian Hayati. $13: 7-13$. 